\title{
Proximate, Chemical and Functional Properties of Wheat, Soy and Moringa Leaf Composite Flours
}

\author{
Tivde Benedict Verem', Igbabul Bibiana Dooshima², Eke Michael Ojoutu², \\ Oladapo Okanlawon Owolabi ${ }^{3}$, Adetunji Onigbajumo ${ }^{4^{*}}$ (] \\ ${ }^{1}$ Center for Food Technology and Research, Benue State University, Makurdi, Nigeria \\ ${ }^{2}$ Department of Food Science and Technology, Federal University of Agriculture, Makurdi, Nigeria \\ ${ }^{3}$ Department of Agricultural Engineering, Federal University of Technology, Akure, Ondo State, Nigeria \\ ${ }^{4}$ School of Mechanical, Medical and Process Engineering, Queensland University of Technology, Brisbane, Australia \\ Email: *a.onigbajumo@qut.edu.au
}

How to cite this paper: Verem, T.B., Dooshima, I.B., Ojoutu, E.M., Owolabi, O.O. and Onigbajumo, A. (2021) Proximate, Chemical and Functional Properties of Wheat, Soy and Moringa Leaf Composite Flours. Agricultural Sciences, 12, 18-38. https://doi.org/10.4236/as.2021.121003

Received: November 16, 2020

Accepted: January 25, 2021

Published: January 28, 2021

Copyright $\odot 2021$ by author(s) and Scientific Research Publishing Inc. This work is licensed under the Creative Commons Attribution International License (CC BY 4.0).

http://creativecommons.org/licenses/by/4.0/

\begin{abstract}
The study presents the effect of utilizing wheat, soy and moringa leaf flour and quality analysis of the flour. The composite flour was prepared using refined wheat flour, soy flour and moringa leaf flour. Four composite flour, compositions were formulated such as $100 \%$ wheat flour (control) designated as sample A. Sample B consisted of $75 \%$ wheat, $20 \%$ soybean and $5 \%$ moringa leaf. Sample C consisted of $70 \%$ wheat, $20 \%$ soybean and $10 \%$ moringa leaf. Sample D was $65 \%$ wheat, $20 \%$ soybean and $15 \%$ moringa leaf. Sample E was $60 \%$ wheat, $20 \%$ soybean and $20 \%$ moringa leaf, respectively. Proximate, chemical, and functional properties of wheat, soy and moringa leaf flours were studied in composite flour variation and preparations. The present study highlighted the nutrients enrichment of flour on incorporation of soy and moringa leaf. Relevant statistical tests were done to analyse the significance of means for all tested parameters. Composite flour composition with $20 \%$ soybean was identified to produce optimal nutrient, mineral quality and yield. The addition of soybean and moringa flour in baked products has been shown in this study to improve the nutrition and health benefits of the body. It also serves as a good cut on the cost of wheat importation in communities with supply challenges.
\end{abstract}

\section{Keywords}

Proximate Analysis, Composite Flour, Soybeans Wheat Flour and Moringa Leaf 


\section{Introduction}

Composite flour has been defined in numerous researches as a combination of wheat and non-wheat flours to produce bread and other baked product [1]. It is the use of wheat and non-wheat flour. It is also the binary or ternary mixture of flour from other crops with or without the addition of wheat flour [1] [2]. Composite flour technology was initiated by the food and health organization was targeted to reducing the cost of support for temperate countries by encouraging the utilization of viable substitutes such as yam, cassava for wheat flour [3] [4] [5]. Efforts have been made to promote the use of composite flours in which flour from locally grown and high protein crops will replace a portion of wheat flour. This blend is expected to be used in bread and other bread product, thereby decreasing the demand for imported wheat and producing protein enriched bread. Although there is now a substantial amount of available composite bread technology, such breads still require at least 70 percent wheat flour to be able to rise [2].

Wheat flour approximately consists of $72 \%$ carbohydrates, $8 \%$ to $13 \%$ protein, $12 \%$ to $13 \%$ moisture, $2.5 \%$ sugar, $1.5 \%$ fat, $1.0 \%$ soluble protein and $0.5 \%$ minerals salts [4] [5]. Wheat flour is the main ingredient used in the manufacturing of bread, noodles and characteristics of wheat used for milling are very important [6] [7]. The use of wheat and soybeans will balance the amino acids and may also improve the nutritive value of cereal-based food products [8]. Therefore, legumes can be successfully used in breads and other baked products to obtain protein-enriched foods with improved amino acid balance [9] [10].

Soybean is one of the most important oil and protein crops of the world containing $30 \%$ to $45 \%$ protein [11]. It is an excellent source of protein because it contains all the essential amino acids, is very rich in minerals and is a good source of fat-soluble vitamins [12]. Therefore, the inclusion of soybeans, Moringa oleifera, defatted sesame, pomegranate peel, and cray fish flour in wheat will enhance the nutrients of the product [7] [13] [14]. Moringa leaves are a good source of micronutrients and are concentrated with protein [15] [16]. The leaves are exceptionally excellent source of $\beta$-carotene, vitamin $\mathrm{C}$, calcium, iron, potassium, magnesium, selenium, zinc, and a good balance of all the essential amino acids [17] [18]. Moringa leaf proteins ranged from 29.1 to $35.3 \mathrm{~g} / 100 \mathrm{~g}$ dry weight [19]. The formulation of wheat, soybeans and moringa leaf would diversify their use, enhance value addition and nutritional content of the bread and other baked products, especially the micronutrients.

Limited researches are available on the use of soybean and Moringa as non-wheat flour addition for composite flour. This study therefore intends to investigate the functional nutrient and mineral properties of the addition of soybean and Moringa leaf flour as protein and vitamin rich plant as composite flour in wheat.

\section{Materials and Method}

The Moringa leaves used in this research study were collected from Federal 
University of Agriculture, Makurdi farm and the soybean were purchased at the seed store house in Barnada office premises Makurdi. The specimens were both identified at the botany laboratory, Benue State University, Makurdi, North Central, Nigeria as Moringa oleifera and Glycine Max, respectively. Wheat flour was purchased at modern market Makurdi town of Benue State, Nigeria.

\subsection{Preparation of Raw Materials}

Soybeans flour was produced using the method of Akubor et al. [20] modified by cleaning manually and washing before boiling. Soybeans were manually cleaned by hand picking the chaff and the stones. The cleaned soya beans were washed with water in order to remove the adhering dirt and pour in heated water of $100^{\circ} \mathrm{C}$ to boil for 30 minutes to remove the anti-nutritional factors and beany flavour. The boiled soya beans were dehulled and washed properly. The grains were dried in an oven (Pax $2 \& \operatorname{Pax} 3$ vented oven lid 2.0) at $60^{\circ} \mathrm{C}$ for $24-48$ hours to a moisture content of about $10 \%$. The dried grains were milled using Attrition milling machine and the flour was sieved into fine flour of uniform particle size by passing them through a $0.4 \mathrm{~mm}$ mesh sieve and packaged in polyethylene bags and kept at room temperature for later use. The flow chart to produce soy flour is shown in Figure 1.

Moringa leaf flour was produced using the method of Aye [21]. Moringa leaves were removed by hand from the stems and washed in water to remove dirt and other contaminants. The leaves were removed from water using plastic baskets and allow for 30 minutes to drain the water. The leaves were spread on clean sacks and dried in a clean house at room temperature for 25 days. The leaves were pounded in a mortar and later milled or grinded to pass through a $0.4 \mathrm{~mm}$ sieve mesh size, the moringa leaves flour were packaged in airtight containers for later use. The flow chart to produce moringa leaf flour is shown in Figure 2.

\subsection{Formulation of Flour Blends}

Composite flour of wheat, soybean and moringa leaf samples were prepared as reported below. The five (5) blends were formulated by replacement as follows. One hundred percent wheat (100\% wheat) flour was the control designated as sample A. Sample B consisted of $75 \%$ wheat, $20 \%$ soybean and $5 \%$ moringa leaf. Sample C consisted of $70 \%$ wheat, $20 \%$ soybean and $10 \%$ moringa leaf. Sample D was $65 \%$ wheat, $20 \%$ soybean and $15 \%$ moringa leaf. Sample E was $60 \%$ wheat, $20 \%$ soybean and $20 \%$ moringa leaf, respectively. The blends were thoroughly mixed using a Kenwood blender (BLG 450 Blender/Grinder) to achieve uniform blending and the ratio of the formulation in $\mathrm{w} / \mathrm{w}$ is as shown in Table 1.

\subsection{Proximate Analyses of Wheat, Soy and Moringa Leaf Composite}

The moisture, ash, fat, crude fiber, protein contents of the flour was determined 
using the method of Association of Official Analytical Chemist (AOAC) [22]. The carbohydrate content would be determined by difference. Therefore, the total sum of the percentage of moisture, ash, fat, crude fiber, and protein was subtracted from the sum total composition, following the method of Egounlety [23].

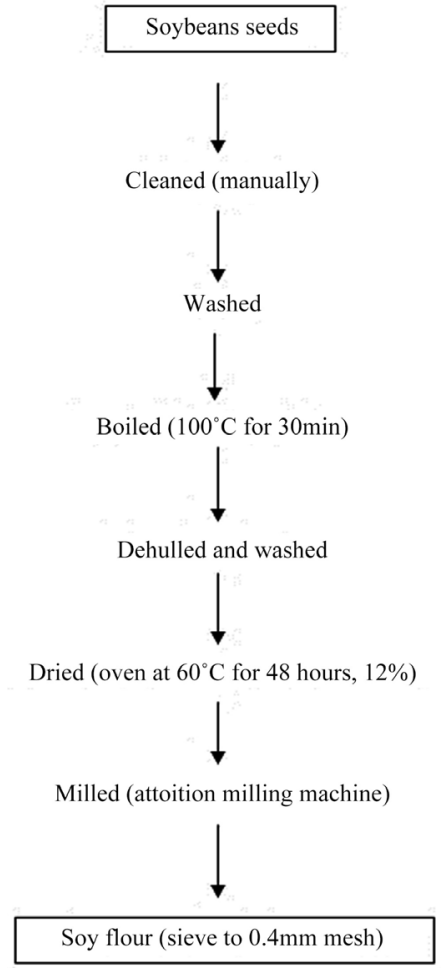

Figure 1. Flow chart for preparation of soybeans flour [20].

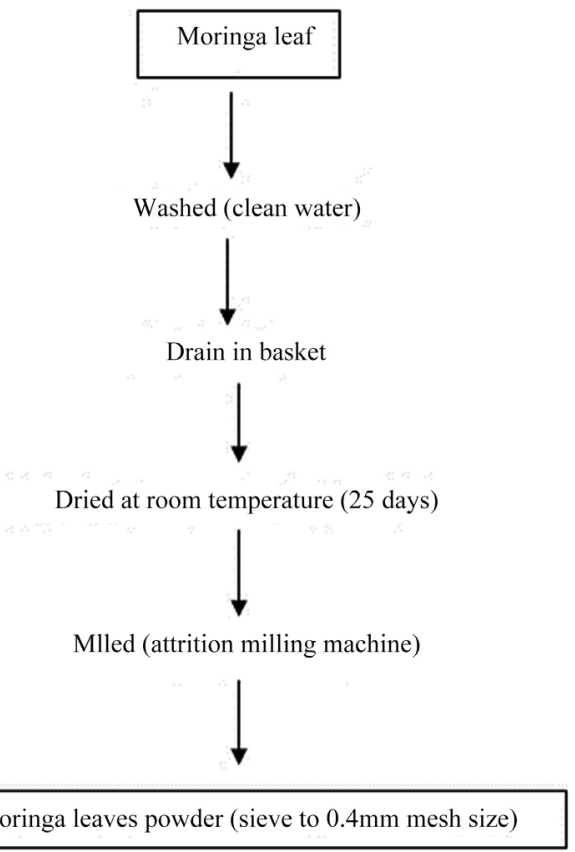

Figure 2. Flow chart for preparation of moringa leaf powder [21]. 
Table 1. Formulation of wheat, soybean and moringa leaf composite flour.

\begin{tabular}{cccc}
\hline iSamples & Wheat $\%$ & soybeans $\%$ & moringa leaf $\%$ \\
\hline A & 100 & 0 & 0 \\
B & 75 & 20 & 5 \\
C & 70 & 20 & 10 \\
D & 65 & 20 & 15 \\
E & 60 & 20 & 20 \\
\hline
\end{tabular}

${ }^{\mathrm{i}}$ Composite flour samples A - E to produce bread and other baked products.

\subsubsection{Determination of Protein}

About $2 \mathrm{~g}$ of the flour sample was weighed into a digestion tube and $15 \mathrm{~mL}$ of concentrated $\mathrm{H}_{2} \mathrm{SO}_{4}$ was added to dissolve the sample. Kjedhal tablets were added to start up the digestion process in a fume cupboard pre-set at $410^{\circ} \mathrm{C}$ for 45 minutes until it gives a clear solution and $75 \mathrm{~mL}$ of distilled water was added to prevent it from solidifying after digestion. The tube was placed in a distilling unit and $50 \mathrm{ml}$ of $40 \% \mathrm{NaOH}$ dispensed into the diluted solution, and the digested distillate into $25 \mathrm{ml}$ of $40 \%$ boric acid for 5 minutes. The distillate was titrated against $0.47 \mathrm{HCl}$ until the first grey colour was seen. A blank was first run, and the titre value was recorded in line with AOAC [22]. The percentage nitrogen is a product of total nitrogen and the conversion factor.

$$
\text { Total Nitrogen }=\frac{\text { Titre value } \times 14.01 \times 0.47}{\text { Weight of sample } \times 100}
$$

Molecular weight of nitrogen $=14.0$, molarity of $\mathrm{HCl}=0.47$, conversion factor $=6.25$.

\subsubsection{Determination of Moisture Content}

The moisture content of flour sample was determined using the force air oven. (AOAC, 2015) [22]. This method involves the measurement of weight lost due to the evaporation of water and other components.

$\%$ Moisture $=\frac{(\text { weight } \text { of dish }+ \text { sample before drying })-(\text { weight of dish }+ \text { sample after drying })_{1}}{(\text { weight of dish }+ \text { sample before drying })} \times 100$

A clean dish with a lid was dried in an oven at $100^{\circ} \mathrm{C}$, it was cooled in a desiccator and weighed. Two grams of the sample was weighed into the dish. The dish with its content was put in the oven at $105^{\circ} \mathrm{C}$ and dried to a constant weight. The moisture content was calculated as the percentage of the original sample weight.

\subsubsection{Determination of Ash Content}

Using the AOAC method, sample of $5 \mathrm{~g}$ was weighed into an ash dish that has been ignited, cooled in a desiccator, and weighed soon after reaching room temperature. It was ignited in a muffle furnace at $550^{\circ} \mathrm{C}$ for $6-7$ hours. The dish was cooled in a desiccator and weighed soon after reaching room temperature. 
The procedure was repeated for the remaining samples and the total ash was calculated as the percentage of the original sample weight as shown below:

$$
\% \text { Ash }=\frac{(\text { weight of empty dish }+ \text { content after ashing })-(\text { weight of empty dish }+ \text { sample })}{(\text { Weight of empty dish })-(\text { weight of empty dish }+ \text { content after ashing })} \times 100
$$

\subsubsection{Determination of Fat Content}

Flour sample of $10 \mathrm{~g}(\mathrm{~W})$ was weighed and put into a test tube. $10 \mathrm{ml}$ of conc. $\mathrm{HCl}$ was added and put in a boiling water bath until solid particles dissolve and the mixture became brown. It was taken off and cooled, then transferred into a separating funnel. $10 \mathrm{~mL}$ of ethanol and $30 \mathrm{~mL}$ of diethyl ether was added and shake, the solution was left to stand and separate.

A clean dried conical flask $\left(\mathrm{W}_{1}\right)$ was weighed and the ether layer was taken into the conical flask. The extraction was repeated twice with $25 \mathrm{~mL}$ of diethyl ether and the solvent was evaporated in a water bath. The fat at $105^{\circ} \mathrm{C}$ in an oven was Cooled and weighed $\left(\mathrm{W}_{2}\right)$. The procedure was repeated for the remaining samples and the \% fat was calculated as shown below:

$$
\% \text { Fat }=\frac{\left(\text { Weight of dried conical flask }+ \text { content after drying }{ }_{2}\right)-\text { Weight of dried conical flask }}{1} \times 100
$$

\subsubsection{Determination of Crude Fibre}

Crude fibre was determined using the method of AOAC [22]. About $2 \mathrm{~g}$ of flour samples were weighed into a $600 \mathrm{~mL}$ long beaker. About $200 \mathrm{~mL}$ of hot $1.25 \%$ $\mathrm{H}_{2} \mathrm{SO}_{4}$ was added. Beaker was placed on digestion apparatus with preheated plates, boiled, refluxed for 30 mins and filtered through Whiteman GF/A paper by gravity. The beaker was rinsed with distilled water. The residue was washed on the paper with distilled water until the filtrate was neutral. The residue was transferred from the paper back to the beaker containing $200 \mathrm{~mL}$ of hot 1.25\% $\mathrm{NaOH}$. Steps 4 and 5 were repeated. The paper with residue was transferred into a crucible, dried at $100^{\circ} \mathrm{C}$ overnight, cooled in a desiccator and reweighed (weight A). The samples were put in furnace at $600^{\circ} \mathrm{C}$ for $6 \mathrm{hrs}$, cooled in a desiccator and reweighed (weight $\mathrm{B}$ ). The loss in weight during incineration represents the weight of crude fibre.

$$
\% \text { crucible fibre }=(\text { weight } \mathrm{A})-(\text { weight } \mathrm{B}) \times 100
$$

\subsubsection{Determination of Carbohydrate}

The method of (AOAC, 2015) [22] was used to calculate the carbohydrate value. The carbohydrate content of each sample was determined using the formula below:

$$
\text { Carbohydrate }=100-(\% \text { moisturecontent }+\% \text { ash }+\% \text { protein }+\% \text { fat })
$$

\subsubsection{Determination of Calorific Content of Composite Flour from Wheat, Soy and Moringa Leaf}

The calorific value was calculated using the method of (AOAC, 2015) [22]. The 
value was obtained for protein, fats and carbohydrates were used to calculate the calorific content value of the sample as expressed below

$$
\text { CalorificValue }\left(\frac{\mathrm{KCal}}{100 \mathrm{~g}}\right)=(\text { Protein } \times 4.0)+(\text { Fat } \times 9.0)+(\text { Carbohydrate } \times 3.75)
$$

\subsection{Determination of Functional Properties of Composite Flour from Wheat, Soybean and Moringa Leaf}

Foaming capacity (FC) was determined by the method of Sathe et al. [24]. The volume of foam at $30 \mathrm{sec}$ of whipping was expressed as FC. The volume of foam was recorded $1 \mathrm{~h}$ after whipping to determine FC as a percent composition of the initial foam volume. Bulk density was determined by the method of Onimawo and Egbekwun [25]. Water and oil absorption capacities were determined following the methods of Sosulski et al. [26]. Swelling index was determined by the method of [25].

\subsubsection{Foaming Capacity}

This was determined by the method described by Coffman and Garcia [27]. About $2 \mathrm{~g}$ of sample was blended with $100 \mathrm{~mL}$ distilled water in a Kenwood blender. The suspension was whipped in an ace homogenizer (NSEIAM-6) at $1600 \mathrm{rpm}$ for $5 \mathrm{~min}$. The mixture was poured into a $250 \mathrm{~mL}$ graduated cylinder and the volume was recorded after $30 \mathrm{sec}$. The foaming capacity was expressed as percentage increase in volume using the formula:

$$
\text { Foam Capacity }=\frac{\text { Volume after whipping }- \text { Volume before whipping }}{\text { Volume before whipping }} \times 100
$$

\subsubsection{Bulk Density}

Bulk density was determined by the method described by Onwuka et al. [28]. Ten $(10 \mathrm{~mL})$ capacity graduated measuring cylinder was filled gently with each sample. The bottom of the cylinder was gently tapped on a laboratory bench several times until there was no further diminution of the sample level. Bulk density was calculated as shown below.

$$
\text { Bulk Density }=\frac{\text { Final Weight }- \text { Initial Weight }}{\text { Volume }}
$$

\subsubsection{Water Absorption Capacity (WAC)}

This was determined using the method of Sosulski et al. [26] and Ikpeme et al. [29]. One gram of the sample was dispensed into a weighed centrifuge tube with $10 \mathrm{ml}$ of distilled water and mixed thoroughly. The mixture was allowed to stand for 1 hour before being centrifuged at $3500 \mathrm{rpm}$ for 30 minutes. The excess water (unabsorbed) was decanted and the tube inverted over an adsorbent paper to drain dry. The weight of water absorbed was determined by difference. The water absorption capacity was calculated as:

$$
\text { WAC }=\frac{\text { Volume of water used }- \text { Volume of free water }}{\text { Weight of sample used }} \times 100
$$




\subsubsection{Swelling Index}

The flour for the bread samples was analysed to obtain the value for the swelling index. The method described by Ukpabi and Ndimele [30] was used. Ten grams $(10 \mathrm{~g})$ of the sample was measured into a $300 \mathrm{~mL}$ measuring cylinder. Then 150 $\mathrm{mL}$ of distilled water was added to the sample and allowed to stand for four hours. The final volume after swelling was recorded. The percentage swelling was calculated as:

$$
\text { Swelling Index } \%=\frac{\text { Final Volume }- \text { Initial Volume }}{\text { Initial Volume }} \times 100
$$

\subsubsection{Oil Absorption Capacity}

The oil absorption capacity was performed in line with the method described by Sosulski et al. [26]. $10 \mathrm{~mL}$ distilled oil was mixed with $1 \mathrm{~g}$ of the flour sample, the mixture was allowed to rest at $30^{\circ} \mathrm{C} \pm 2{ }^{\circ} \mathrm{C}$ for $30 \mathrm{~min}$ and then centrifuged at $200 \mathrm{xg}$ for $30 \mathrm{~min}$.

\subsection{Determination of Mineral Content of Composite Flours from Wheat, Soy and Moringa Leaf}

Two grams ( $2 \mathrm{~g})$ of each composite flour sample were weighed into a clean ceramic crucible using the method of AOAC [22]. A blank was prepared with empty crucible. The crucible was placed in a muffle furnace at $500^{\circ} \mathrm{C}$ for 4 hours. The samples were allowed to cool down in the oven after which it was removed carefully. The ash samples were poured into already labelled $50 \mathrm{~mL}$ centrifuge tube. The crucible was rinsed with $5 \mathrm{~mL}$ of distilled water into the centrifuge tube. The crucible was rinsed again with $5 \mathrm{~mL}$ of aqua regid. This was repeated to make a total volume of $20 \mathrm{~mL}$. The sample was mixed properly and centrifuged by $10 \mathrm{~min}$. The supernatant was decanted into clear vials for minerals determination. The absorbance was read on atomic absorption spectrophotometer (Buck Scientific Model 200A) at different wavelengths for each mineral element.

\subsubsection{Determination of Zinc}

Zinc in the samples of composite four was determined according to Onwuka [31] by molybdate method using hydroquinone as a reducing agent. Five milliliters $(5 \mathrm{~mL})$ of the test solution was pipetted into $50 \mathrm{ml}$ graduated flask. Then 10 $\mathrm{mL}$ of molybdate mixture was added and diluted to mark with water. It was allowed to stand for 30 minutes for colour development. The absorbance was measured at $660 \mathrm{~nm}$ against a blank. A curve relating absorbance to $\mathrm{mg}$ zinc present was constructed. Using the zinc standard solution, and following the same procedure for the test sample, a standard curve was plotted to determine the concentration of zinc in the composite flour sample.

$$
\% \text { Zinc }=\frac{\text { graph reading } \times \text { solution volume }}{100}
$$

\subsubsection{Determination of Iron}

Iron was determined following the phenanthroline method of Lee and Stumm 
[32]. Five milliliters of digested sample of composite four was placed in a $50 \mathrm{~mL}$ volumetric flask. Then $3 \mathrm{~mL}$ of phenanthroline solution, $2 \mathrm{~mL}$ of hydrochloric acid and $1 \mathrm{~mL}$ of hydroxylamine solution were added to the sample in sequence. The sample solution was boiled for 2 minutes and $9 \mathrm{ml}$ of ammonium acetate buffer solution was added to the solution. The solution was diluted with water to $50 \mathrm{~mL}$ volume. The absorbance was determined at $510 \mathrm{~nm}$ wavelength. Iron standard solution was prepared in order to plot a calibration curve to determine the concentration of the sample. Standard solution containing $100 \mathrm{mg} / \mathrm{mL}$ of ferric irons was prepared from $1 \mathrm{~g}$ pure iron wires. The wires were dissolved in $100 \mathrm{~mL}$ concentrated nitric acid, boiled in a water bath and diluted to $100 \mathrm{~mL}$ with distilled water after cooling. Standard solutions of known concentrations were prepared by pipetting 2, 4, 6, 8 and $10 \mathrm{~mL}$ standard iron solution into 100 $\mathrm{mL}$ volumetric flasks and made up to volume.

\subsubsection{Determination of Potassium}

Potassium was determined by a procedure described by Osborne and Voogt [33] using a flame photometer. Potassium standard was prepared. The standard solution was used to calibrate the instrument read out of composite four. The meter reading was at $100 \% \mathrm{E}$ (emission) to aspire the top concentration of the standards. The $\% \mathrm{E}$ of all the intermediate standard curves were plotted on linear graph paper with these readings. The sample solution was aspired on the instrument and the readings (\% E) were recorded. The concentration of the element in the sample solution was read from the standard curve.

$$
\% \text { Potassium }=\frac{\mathrm{Ppm} \times 100 \times \mathrm{DF}}{1 \text { million }}
$$

\subsubsection{Determination of Calcium}

Calcium was determined using the method described by Pearson [34]. Twenty-five milliliter $(25 \mathrm{~mL})$ of the digested samples of composite four was pipetted into $250 \mathrm{~mL}$ conical flask and a pinch of Eriochrome Black-T-Indicator (EBT) was added. Thereafter, $2 \mathrm{~mL}$ of $0.1 \mathrm{~N} \mathrm{NaOH}$ solution was added and the mixture titrated with standard EDTA (0.01M EDTA) solution.

Calcium $(\mathrm{mg} / \mathrm{L})=\frac{\text { Titre value } \times \text { Molarity of EDTA } \times \text { Equiv. Wt. of calcium } \times 1000}{\text { Vol. of sample used }}$

\subsection{Determination of Vitamins Content of Composite Flour of Wheat, Soy and Moringa Leaf}

\subsubsection{Determination of Vitamin A}

The AOAC [35] method using the colorimeter was adopted for determination of either flour. This measures the unstable colour at the absorbance of $620 \mathrm{~nm}$ that result from the reaction between vitamin A and SbL3. 100 volume solution $\times$ reading graph million $1 \mathrm{DF} \times 100 \times$ Ppm Pyrogallol (antioxidant) was added to 2 g sample of either flour or bread prior to saponification with $200 \mathrm{ml}$ alcoholic $\mathrm{KOH}$. The saponification took place in water bath for 30 minutes. The solution 
was transferred to a separating funnel where water was added. The solution was extracted with $1-2.5 \mathrm{~mL}$ of hexane. The extraction was washed with equal volume of water. The extract was filtered through filter paper containing $5 \mathrm{~g}$ anhydrous $\mathrm{Na}_{2} \mathrm{SO}_{4}$ into volumetric flask. The filter paper was rinsed with hexane and made up to volume. The hexane was evaporated from the solution and blank. About $1 \mathrm{~mL}$ chloroform and SbL3 solution were added to the extract and 32 blanks. The reading of the solution and blank was taken from the colorimeter adjusted to zero absorbance or $100 \%$. Calculation

Vit $\mathrm{A}(\mathrm{mg})=$ Absorbance at $620 \mathrm{~nm} \times$ Std. curve slope $\times\left(\right.$ Final $\frac{\text { Volume }}{\text { Sample }} \mathrm{Wt}$. $)$

\subsubsection{Determination of Vitamin C}

Metaphosphoric acid-acetic solution $(5 \mathrm{~mL})$ was pipette and added to a $2 \mathrm{~mL}$ ascorbic acid standard solution in Erlenmeyer flasks in triplicates. The composite four was titrated against indophenols solution until a distinct rose-pink colour formed and persisted for more than $5 \mathrm{sec}$. The initial and final readings of the burette were recorded. Blanks were prepared in the same way as above and the average titre of indophenols dye used was calculated.

The pulverized mixed fruit leather pieces were dissolved in water and $2 \mathrm{~mL}$ sample of composite four or leavened and unleavened bread was added to $5 \mathrm{~mL}$ of metaphosphoric acid-acetic acid solution in a $50 \mathrm{~mL}$ Erlenmeyer flask and was titrated with the indophenol dye solution until a distinct rose-pink colour persisted for more than $5 \mathrm{~s}$. This was done in triplicate and the initial and final readings of the burette were taken and used to calculate the average titre of dye used.

\subsubsection{Determination of Vitamin $\mathrm{B}_{1}$ (Thiamine)}

Thiamine content was determined using the scalar analyzer method of AOAC [22]. Five grams ( $5 \mathrm{~g}$ ) of each sample of composite four was homogenized in 5 $\mathrm{ml}$ normal ethanoic sodium hydroxide solution. The homogenate was filtered and made up to $100 \mathrm{ml}$ with the extract solution. A $10 \mathrm{ml}$ aliquot of the extract was dispensed into a flask and $10 \mathrm{mls}$ of potassium dichromate solution added. The resultant solution was incubated for 15 mins at room temperature $\left(25^{\circ} \mathrm{C} \pm\right.$ $331^{\circ} \mathrm{C}$ ). The absorption was read from the spectrophotometer at $360 \mathrm{~nm}$ using a reagent blank to standardize the instrument at zero. The thiamine content was calculated as follows:

Vit B1 $($ Thiamine $\mathrm{mg} / 100 \mathrm{~g})=\frac{100}{\text { Sample Wt. }} \times \frac{\text { Sample Absorbance }}{\text { Conc. of Soln. }} \times$ Conc.$\times$ Dil. Factor

\subsubsection{Determination of Vitamin $B_{2}$ (Riboflavin) and Vitamin $B_{3}$}

Riboflavin was determined according to AOAC [22] methods. Two grams (2 g) of composite four samples were placed in a conical flask and $50 \mathrm{ml}$ of $0.2 \mathrm{~N} \mathrm{HCl}$ was added to the sample, boiled for 1 hour, and then cooled. The $\mathrm{pH}$ was adjusted to 6.0 using sodium hydroxide $1 \mathrm{~N} \mathrm{HCl}$ was added to the sample solution 
Vit. B2 $=\frac{(\text { Sample Rd. }- \text { Blank Rd. })}{(\text { Sample Rd. }- \text { Blank Rd. })-(\text { Sample Rd. }+ \text { Std. Tube }- \text { Sample Rd. }+ \text { Std. Blank })} \times \frac{1}{\text { Sample Wt. }}$

\section{Results and Discussion}

\subsection{Proximate Composition and Energy Values of Wheat, Soybean and Moringa Leaf Composite}

Table 2 shows the proximate composition and energy value of wheat, soybean and moringa leaf composite flour. The protein content of Sample A-E varied from $10.24 \%-28.81 \%$ that was $5 \%-10 \%$ level of significant with sample A containing the least value of $10.24 \%$ while sample E had the highest value of $28.81 \%$. The protein content of the flour increased with a decrease in wheat, an increase in moringa leaf and $20 \%$ soybean flour constant. The low protein content of sample A (control) could be because of $100 \%$ wheat flour and wheat is deficient in protein [36] [37]. The increase was significant at $5 \%$ level of probability. This result agrees with the work done by Teixeria et al. [38] and Soetan et al. [39] who reported on fractionation of protein from moringa leaves, protein in the moringa seeds and leaves of African locust bean.

Table 2. Proximate composition (\%) and energy value (kcal/100g) of flour blends from wheat, soybean and moringa leaf composite flours.

\begin{tabular}{|c|c|c|c|c|c|c|c|}
\hline Sample & Protein & Fat & Crude fibre & Ash & Moisture & Carbohydrate & $\begin{array}{c}\text { Calorific value } \\
\text { (kcal/100mg) }\end{array}$ \\
\hline A & $10.24^{\mathrm{e}} \pm 0.03$ & $1.52^{\mathrm{e}} \pm 0.01$ & $2.05^{\mathrm{e}} \pm 0.03$ & $5.60^{e} \pm 0.02$ & $10.20^{\mathrm{a}} \pm 0.42$ & $67.67^{a} \pm 0.01$ & $328.40^{\mathrm{d}} \pm 0.28$ \\
\hline B & $19.88^{\mathrm{d}} \pm 0.03$ & $1.54^{\mathrm{d}} \pm 0.00$ & $2.25^{\mathrm{d}} \pm 0.01$ & $6.11^{\mathrm{d}} \pm 0.01$ & $10.59^{\mathrm{e}} \pm 0.04$ & $60.83^{\mathrm{b}} \pm 0.01$ & $321.49^{\mathrm{a}} \pm 0.01$ \\
\hline C & $22.52^{c} \pm 0.01$ & $1.85^{c} \pm 0.03$ & $2.50^{c} \pm 0.00$ & $7.10^{c} \pm 0.01$ & $11.021^{\mathrm{d}} \pm 0.03$ & $55.77^{\mathfrak{c}} \pm 0.01$ & $315.87^{b} \pm 0.04$ \\
\hline $\mathrm{D}$ & $25.83^{\mathrm{b}} \pm 0.02$ & $2.16^{\mathrm{b}} \pm 0.01$ & $2.80^{\mathrm{b}} \pm 0.01$ & $7.92^{\mathrm{b}} \pm 0.03$ & $11.74^{c} \pm 0.06$ & $49.55^{\mathrm{d}} \pm 0.03$ & $308.57^{\mathfrak{c}} \pm 0.03$ \\
\hline $\mathrm{E}$ & $28.81^{\mathrm{a}} \pm 0.01$ & $2.37^{\mathrm{a}} \pm 0.02$ & $3.00^{\mathrm{a}} \pm 0.14$ & $8.66^{\mathrm{a}} \pm 0.02$ & $12.22^{\mathrm{b}} \pm 0.04$ & $44.94^{\mathrm{e}} \pm 0.01$ & $305.10^{\mathrm{e}} \pm 0.03$ \\
\hline LSD (0.05) & 0.06 & 0.05 & 0.17 & 0.06 & 0.50 & 0.05 & 0.33 \\
\hline
\end{tabular}

Values are shown as mean \pm standard deviation of replicates ( 3 repetitions of each group were made with mean average presented for robust analysis). Mean values followed by different superscripts in a column are significantly different $(\mathrm{P}<0.05)$. Key: $\mathrm{A}=(100 \% \mathrm{Wheat}), \mathrm{B}=(75 \% \mathrm{Wheat}, 20 \%$ Soybeans, $5 \%$ Moringa leaf $), \mathrm{C}=(70 \%$ Wheat, $20 \%$ Soybeans, $10 \%$ Moringa leaf $), \mathrm{D}=(65 \%$ Wheat, $20 \%$ Soybeans, $15 \%$ Moringa leaf $), \mathrm{E}=(60 \%$ Wheat, $20 \%$ Soybeans, $20 \%$ Moringa leaf), LSD = Least Significant Different. 
The fat content of the wheat, soybeans and moringa leaf flour varied from sample A - E (1.52\% - 2.37\%), with sample A comprising of the least value of $1.52 \%$ while sample E recorded the highest value of $2.37 \%$. The fat content increased with increase in moringa leaf flour and $20 \%$ soybean flour. The increase in fat content was moderately low with significant decrease in wheat flour, increase in moringa leaf and $20 \%$ soybeans constant. The low increase in fat could elongate the storage performance of the composite flour as rancidity may occur in the flour blends of high amount of fats. The increased was significant at $5 \%$ level of probability following the work of Soetan et al. [39] on the fat content of African locust beans.

The crude fibre augmented from 2.05\% - 3.00\% of Sample A - E with sample A registering the smallest value of $2.05 \%$ meanwhile sample E encompassed the largest value of $3.00 \%$. The crude fibre content of the flour enhanced with increase in moringa leaf flour and $20 \%$ soybean flour constant. This could be so as soybean and moringa leaf are excellent source of fibre as reported by Gidamis et al. [40] and Sivakumar [41] based on previous report on adsorption study on municipal solid waste leachate using moringa seed. The increase was significant at $5 \%$ level of probability.

The Ash content of the composite flour varied from $5.60 \%-8.66 \%$ of Sample A - E with sample A containing the least value of $5.60 \%$ while sample E had the highest value of $8.66 \%$. The ash content increased with increase in moringa leaf flour and 20\% soybean flour. The increase was significant at $5 \%$ level of probability. The ash content of the samples increased with increase in the moisture content of the flour formulations. These findings agree with the work done by Iskandar et al., [42] on moringa leaf extracts supplementation and Abdelghafor et al. [43] on the ash content of composite flour of sorghum and hard white wheat. Increase in ash content of the flour shows that samples with high amount of ash will be excellent in mineral content.

The Moisture content arranged from 5\% - 10\% (Sample A - E) with sample A comprising the least value of $10.20 \%$ while sample $E$ had the highest value of $12.22 \%$ which is in agreement with the research work of Nour and Ibrahim [44] on moisture effect of supplementation with moringa leaf powder and Alaunyte et al. [45] on combination of enzymes in straight dough. The moisture content increased with decrease in the carbohydrate value of the samples enhancing nutritional products.

The carbohydrate content assorted from $67.67 \%$ - $44.94 \%$ of Sample A comprising the highest value of $67.67 \%$ while sample $\mathrm{E}$ had the lowest value of 44.94\%. The carbohydrate value decreased with increase in moringa leaf flour and $20 \%$ soybean flour. The decrease was significant at $5 \%$ level of probability and the carbohydrate value decreased between the flour samples which create room for high amount of nutrients. This finding is in line with the work done by Nour and Ibrahim [46] and, Steyn and Mchiza [47] on millet flour supplementa- 
tion with moringa seeds. This is in addition to Freire et al. [48] on obesity and carbohydrate in Sub-Saharan Africa reported under nutrition and excess body weight.

The Calorific value ranged from 328.40\% - 305.10\% (Sample A - E) with the variation of $5 \%-10 \%$ level of significant with sample A recording the highest energy value of $328.40 \%$ with sample E containing the lowest calorific value at $305.10 \%$. The calorific content decrease with decrease in wheat flour, increase in moringa leaf flour and $20 \%$ soybean flour. This agrees with the report of Alaunyte et al. [45] on combination of enzyme in straight dough and sourdough bread making. The carbohydrate content and calorific value of the formulated samples decreased with increase in composite flour of soybeans and moringa leaf flour blends, this could be attributed to high protein, fibre, ash and moisture content of soybeans and moringa leaf flour combined with decrease in wheat flour.

\subsection{Functional Properties of the Composite Flour of Wheat, Soybeans and Moringa Leaf}

Table 3 shows the functional properties of the wheat, soybeans and moringa leaf flour before value addition. Foaming capacity, bulk density, water absorption capacity, swelling index and oil absorption capacity of the flours were evaluated. Functional properties are the characteristics that determine the suitability of the food material for specific purpose. Foaming capacity of the composite flour for the production of bread decrease from $29.26 \%$ sample A to $18.50 \%$ Sample B and later raise to $22.20 \%$ Sample C, 25.89\% Sample D and $29.60 \%$ Sample E having the highest foaming capacity and sample B having the least value. The higher the foaming capacity, the better the reconstitutional properties of the flour which has a marked effect on the kneading quality [49] [50].

Table 3. Functional properties of wheat, soybean and moringa leaf composite flour.

\begin{tabular}{cccccc}
\hline Sample & $\begin{array}{c}\text { Foaming } \\
\text { Capacity (\%) }\end{array}$ & $\begin{array}{c}\text { Bulk Density } \\
(\mathrm{g} / \mathrm{ml})\end{array}$ & $\begin{array}{c}\text { Water Absorption } \\
\text { Capacity (\%) }\end{array}$ & $\begin{array}{c}\text { Swelling } \\
\text { Index }\end{array}$ & $\begin{array}{c}\text { Oil Absorption } \\
\text { Capacity (\%) }\end{array}$ \\
\hline A & $29.26^{\mathrm{a}} \pm 0.03$ & $0.73^{\mathrm{b}} \pm 0.01$ & $80.27^{\mathrm{b}} \pm 0.01$ & $6.73^{\mathrm{a}} \pm 0.01$ & $91.54^{\mathrm{b}} \pm 0.01$ \\
B & $18.50^{\mathrm{d}} \pm 0.14$ & $0.50^{\mathrm{e}} \pm 0.01$ & $56.80^{\mathrm{e}} \pm 0.01$ & $3.56^{\mathrm{e}} \pm 0.02$ & $61.36^{\mathrm{e}} \pm 0.03$ \\
C & $23.50^{\mathrm{c}} \pm 2.12$ & $0.60^{\mathrm{d}} \pm 0.01$ & $68.20^{\mathrm{d}} \pm 0.02$ & $4.30^{\mathrm{d}} \pm 0.02$ & $73.63^{\mathrm{d}} \pm 0.01$ \\
D & $25.89^{\mathrm{b}} \pm 0.04$ & $0.70^{\mathrm{c}} \pm 0.01$ & $79.50^{\mathrm{c}} \pm 0.01$ & $5.00^{\mathrm{c}} \pm 0.01$ & $85.90^{\mathrm{c}} \pm 0.01$ \\
E & $29.60^{\mathrm{a}} \pm 0.28$ & $0.80^{\mathrm{a}} \pm 0.01$ & $91.00^{\mathrm{a}} \pm 0.01$ & $5.70^{\mathrm{b}} \pm 0.00$ & $98.17^{\mathrm{a}} \pm 0.02$ \\
LSD (0.05) & 2.47 & 0.05 & 0.05 & 0.05 & 0.05 \\
\hline
\end{tabular}

Values are shown as mean \pm standard deviation of replicates. Means values followed by different superscripts in a Column are significantly different $(\mathrm{P}<0.05)$. Key: $\mathrm{A}=(100 \%$ Wheat $), \mathrm{B}=(75 \%$ Wheat, $20 \%$ Soybeans, 5\% Moringa leaf), $\mathrm{C}=(70 \%$ Wheat, $20 \%$ Soybeans, $10 \%$ Moringa leaf $), \mathrm{D}=(65 \%$ Wheat, $20 \%$ Soybeans, $15 \%$ Moringa leaf $), E=(60 \%$ Wheat, $20 \%$ Soybeans, $20 \%$ Moringa leaf $)$, LSD = Least Significant Different. 
The value for the bulk density $(\mathrm{g} / \mathrm{ml})$ augmented from $0.73 \%$ to $0.80 \%$ of sample A had the least value and sample E having the highest value. There was a significant difference among the flour samples. Swelling index (\%) was arranged from 6.73 (sample A) to 5.70 (sample E) with $100 \%$ wheat flour recording the highest value of swelling index and sample B recording the least value. Meanwhile, there was significant difference across the samples. Water absorption capacity and oil adsorption capacity were ranges from 80.27 for sample A to 91.0 for sample E respectively. Sample E recorded the highest value and Sample B the least. In oil absorption capacity (sample A) 91.54, (Sample B) 61.36, (Sample C) 73.63, (Sample D) 85.90 and (sample E) 98.17. Meanwhile, there was significant difference $(\mathrm{P}<0.05)$ between the flour formulations.

The swelling index and bulk density values of composite flour in this study is lower than the previous works reported by Wang et al. [50] but agrees with the fact that swelling and bulk density in this research are less than that of cassava flour but generally more than those of maize. Water absorption capacity of sample B which was lower than other samples may be due to moringa leaf having a weaker internal structure as reported by Soliva et al. [51]. Water absorption capacity is a function of water holding ability of the flour sample. It is an important processing parameter that has implication for viscosity in the interim there was a significant difference $(\mathrm{P}<0.05)$ between the samples. This result shows that fortification of wheat with soybeans and moringa leaf flour has a few advantages specifically in nutritional improvement, cost-effectiveness, a key functional benefit (less oil absorption) and overall health benefits [45]. With increase in the formulation there happens a more starch damage than $100 \%$ wheat flour by blending process. With high proportion of starch damage, water absorption rises, and it realizes high starch gelatinization and finally the crumb becomes softer [52] [53].

The result in this work is in an agreement with the work of Coskuner and Karababa [54] that water absorptions of flours used for flat bread production are in wide limits. Although flour that is used for pan bread making has optimum water absorption of $60 \%-65 \%$, flour used for flat bread production has optimum water absorption varying between $38 \%$ and $85 \%$ [54]. The result of composite flour used in this research is in line with the findings of Gernah et al. [37], and, Coskuner and Karababa [54].

\subsection{Mineral Composition of the Composite Flour of Wheat, Soybeans and Moringa Leaf}

Table 4 reported the mineral composition of the composite flour of wheat, soybeans and moringa leaf blends to produce leavened and unleavened bread. The mineral content is indicated across the flour starting with $\mathrm{Zinc}(\mathrm{Zn})$ registered from $0.76 \mathrm{mg} / 100 \mathrm{~g}$ sample A to $15.40 \mathrm{mg} / 100 \mathrm{~g}$ sample $\mathrm{E}$ as a result of decreased in wheat flour, increase in moringa leaf and $20 \%$ soybean flour. There was a significant difference $(\mathrm{P}<0.05)$ across the samples with sample A having 
Table 4. Mineral composition $(\mathrm{mg} / 100 \mathrm{~g})$ of wheat, soybean and moringa leaf flour blends.

\begin{tabular}{ccccc}
\hline Sample & Zinc $(\mathrm{Zn})$ & Iron $(\mathrm{Fe})$ & Potassium $(\mathrm{K})$ & Calcium $(\mathrm{Ca})$ \\
\hline A & $0.76^{\mathrm{e}} \pm 0.01$ & $3.45^{\mathrm{e}} \pm 0.01$ & $184.37^{\mathrm{e}} \pm 0.01$ & $71.47^{\mathrm{e}} \pm 0.01$ \\
B & $9.63^{\mathrm{d}} \pm 0.01$ & $11.76^{\mathrm{d}} \pm 0.01$ & $799.58^{\mathrm{d}} \pm 0.02$ & $705.99^{\mathrm{d}} \pm 0.03$ \\
C & $11.55^{\mathrm{c}} \pm 0.01$ & $14.12^{\mathrm{c}} \pm 0.02$ & $959.50^{\mathrm{c}} \pm 0.02$ & $847.20^{\mathrm{c}} \pm 0.01$ \\
D & $13.48^{\mathrm{b}} \pm 0.01$ & $16.46^{\mathrm{b}} \pm 0.01$ & $1119.41^{\mathrm{b}} \pm 0.01$ & $988.39^{\mathrm{b}} \pm 0.01$ \\
E & $15.40^{\mathrm{a}} \pm 0.01$ & $18.81^{\mathrm{a}} \pm 0.01$ & $1279.32^{\mathrm{a}} \pm 0.00$ & $1129.59^{\mathrm{a}} \pm 0.02$ \\
LSD $(0.05)$ & 0.05 & 0.05 & 0.04 & 0.05 \\
\hline
\end{tabular}

Values are shown as mean \pm standard deviation of replicates. Means values followed by different superscripts in a Column are significantly different $(\mathrm{P}<0.05)$. Key: $\mathrm{A}=(100 \%$ Wheat $), \mathrm{B}=(75 \%$ Wheat, $20 \%$ Soybeans, $5 \%$ Moringa leaf), $\mathrm{C}=(70 \%$ Wheat, $20 \%$ Soybeans, $10 \%$ Moringa leaf $), \mathrm{D}=(65 \%$ Wheat, $20 \%$ Soybeans, $15 \%$ Moringa leaf $), E=(60 \%$ Wheat, $20 \%$ Soybeans, $20 \%$ Moringa leaf $)$, LSD = Least Significant Different.

the least value of zinc content and sample E enclosing the highest content of zinc with increase in moringa leaf and $20 \%$ soybean flour for the formulations. This result concord with the work done by [52] [53] [55] who reported on improving the quality of nutrient-rich bread by combination of enzymes in straight dough and sourdough bread making, influence of the soluble fibre on quality of dough and quality minerals of bread produced from composite flour of wheat, plantain and soybean.

The Iron (Fe) content of the bread formulation increased from $3.45 \mathrm{mg} / 100 \mathrm{~g}$ of sample A to $18.81 \mathrm{mg} / 100 \mathrm{~g}$ of sample E. There was a decreased in wheat flour with increase in moringa leaf and $20 \%$ soybeans. There was a significant difference among the sample blends. The value of potassium $(\mathrm{k})$ is ranged from 184.37 $\mathrm{mg} / 100 \mathrm{~g}$ of sample A to $1279.32 \mathrm{mg} / 100 \mathrm{~g}$ of sample E respectively and there is a significant difference $(\mathrm{P}<0.05)$ between the samples, this finding agrees with the result of [56] [57] who report increase in mineral content of bread fortified with tilapia fish.

The value of Calcium increased from $71.47 \mathrm{mg} / 100 \mathrm{~g}$ sample A to 1129.59 $\mathrm{mg} / 100 \mathrm{~g}$ sample $\mathrm{E}$ this result is within the values of experiment done by [58] [59]. The result shows that there was a significant difference $(\mathrm{P}<0.05)$ between the minerals content across the flour formulation and is also in agreement with the findings of other researchers about the mineral content found in other bread and baked products [19] [60]. The mineral content of the flour increased with increase in the high amount of ash which triggers the formulation of the flour blends to meet up with the required mineral content of the bread products.

\subsection{Vitamin Composition of the Composite Flour of Wheat, Soybean and Moringa Leaf}

The result reported by Table 5 shows the vitamin composition of wheat, soybeans and moringa leaf flour blends. Vitamins $\mathrm{C}$ content varied from 0.23 $\mathrm{mg} / 100 \mathrm{~g}$ of sample A to $18.29 \mathrm{mg} / 100 \mathrm{~g}$ of sample E which reported similar with the work of Olson [19]. In the result of vitamin, A ranged from $0.12 \mathrm{IU} / 100 \mathrm{~g}$ 
Table 5. Vitamin composition $(\mathrm{mg} / 100 \mathrm{~g})$ of wheat, soybean and moringa leaf composite flour.

\begin{tabular}{cccccc}
\hline Sample & Vitamin C & A (IU/100g) & B1 & B2 & B3 \\
\hline A & $0.23^{\mathrm{e}} \pm 0.01$ & $0.12^{\mathrm{e}} \pm 0.01$ & $0.54^{\mathrm{e}} \pm 0.02$ & $0.15^{\mathrm{e}} \pm 0.01$ & $0.07^{\mathrm{e}} \pm 0.01$ \\
B & $11.43^{\mathrm{d}} \pm 0.01$ & $11.70^{\mathrm{d}} \pm 0.01$ & $1.54^{\mathrm{d}} \pm 0.01$ & $7.70^{\mathrm{d}} \pm 0.09$ & $4.02^{\mathrm{d}} \pm 0.00$ \\
C & $13.72^{\mathrm{c}} \pm 0.01$ & $14.04^{\mathrm{c}} \pm 0.01$ & $1.90^{\mathrm{c}} \pm 0.01$ & $9.24^{\mathrm{c}} \pm 0.01$ & $4.82^{\mathrm{c}} \pm 0.01$ \\
D & $16.01^{\mathrm{b}} \pm 0.02$ & $16.38^{\mathrm{b}} \pm 0.01$ & $2.20^{\mathrm{b}} \pm 0.01$ & $10.78^{\mathrm{b}} \pm 0.02$ & $5.62^{\mathrm{b}} \pm 0.01$ \\
E & $18.29^{\mathrm{a}} \pm 0.02$ & $18.72^{\mathrm{a}} \pm 0.01$ & $2.50^{\mathrm{a}} \pm 0.01$ & $12.32^{\mathrm{a}} \pm 0.02$ & $6.43^{\mathrm{a}} \pm 0.00$ \\
LSD (0.05) & 0.05 & 0.05 & 0.01 & 0.02 & 0.01 \\
\hline
\end{tabular}

Values are shown as mean \pm standard deviation of replicates. Mean values followed by different superscripts in a Column are significantly different $(\mathrm{P}<0.05)$. Key: $\mathrm{A}=(100 \%$ Wheat $), \mathrm{B}=(75 \%$ Wheat, $20 \%$ Soybeans, $5 \%$ Moringa leaf $), \mathrm{C}=(70 \%$ Wheat, $20 \%$ Soybeans, $10 \%$ Moringa leaf $), \mathrm{D}=(65 \%$ Wheat, $20 \%$ Soybeans, $15 \%$ Moringa leaf $), \mathrm{E}=(60 \%$ Wheat, $20 \%$ Soybeans, $20 \%$ Moringa leaf $), \mathrm{LSD}=$ Least Significant Different.

for sample A to $18.72 \mathrm{IU} / 100 \mathrm{~g}$ for sample $\mathrm{E}$. This increase in vitamin A content is due to the decrease in wheat flour, increase in moringa leaf and $20 \%$ soybeans and there is a significant difference among the samples. The result of vitamin $B_{1}$ ranges from $0.54 \mathrm{mg} / 100 \mathrm{~g}$ of sample A to $2.50 \mathrm{mg} / 100 \mathrm{~g}$ of sample $\mathrm{E}$. This result indicates that sample A is least with $0.54 \mathrm{mg} / 100 \mathrm{~g}$ and sample $\mathrm{E}$ is $2.50 \mathrm{mg} / 100 \mathrm{~g}$. This shows that the vitamin content of wheat bread increased with increase in moringa leaf [61].

Vitamin $B_{1}$ ranged from $0.54 \mathrm{mg} / 100 \mathrm{~g}$ for sample A to $2.50 \mathrm{mg} / 100 \mathrm{~g}$ for sample E. sample A having the least value and sample $\mathrm{E}$ had the highest value. The increase in vitamin $B_{1}$ resulted in the decrease in wheat flour with increase in moringa leaf and $20 \%$ soybean. There was a significant difference $(\mathrm{p}<0.05)$ among the samples.

Vitamin $B_{2}$ enlarged from $0.15 \mathrm{mg} / 100 \mathrm{~g}$ for sample A to $12.32 \mathrm{mg} / 100 \mathrm{~g}$ for sample $E$. Vitamin $B_{2}$ increased with increase in moringa leaf and $20 \%$ soybean. There was a significant difference $(p<0.05)$ among the samples. Vitamin $B_{3}$ content ranged from $0.07 \mathrm{mg} / 100 \mathrm{~g}$ for sample A to $6.43 \mathrm{mg} / 100 \mathrm{~g}$ for sample $\mathrm{E}$. There was a significant difference $(\mathrm{P}<0.05)$ between the vitamin composition of the flour formulations with sample A having the least vitamin content follow by Sample B, C, D and E. The result of vitamin $B_{2}$ and $B_{3}$ confirms the result obtained in previous studies [62] [63] on the nutrients quality of wheat bread. According to Ebert [8], Moringa leaves powder in combination with soybeans flour is useful as nutritional supplement for treating malnourishment. Therefore, the formulation of wheat, soybeans and moringa flour helps to achieve this purpose.

\section{Conclusions}

In a bid to enhance the nutrient quality of flour across protein, ash, fibre, moisture and fats content, this study investigated the right mix for wheat, soy and 
moringa leaf flour. The quality analysis of different mixes of wheat, soy and moringa leaf flour were obtained and analysed to evaluate the effect of their addition on food quality such as protein, fibre, moisture, ash and fat content.

Protein content of the flour increased with increasing moringa leaf, decreased with up to $20 \%$ soybean flour. Fat composition was observed to moderately reduce as wheat flour reduces with increased moringa leaf at $20 \%$ soybean flour. The calorific value of the flour mix decreases with decreasing wheat, increased moringa leaf flour also at $20 \%$ soybean flour. The mineral content of composite flour of wheat, soybean and moringa leaf such as zinc, iron, potassium and calcium were enhanced with an increase in the formulation of wheat, soybeans and moringa leaf flour. Also, the vitamins such as Vitamin $A, C, B_{1}, B_{2}$ and $B_{3}$ content of the flours significantly increased with an increase in the formulations. The use of soybeans and moringa leaf flour in bread and other baked products would diversify its utilization, enhance nutrition, health benefit and good living of the consumers and reduce the dependence on wheat flour. This could cut down considerably the cost of importing wheat flours for societies with limited production capacity.

\section{Conflicts of Interest}

The authors declare no conflicts of interest regarding the publication of this paper.

\section{References}

[1] Dendy, D.V. (1992) Composite Flour-Past, Present and the Future: A Review with Special Emphasis on the Place of Composite Flour in the Semi-Arid Zones. In: Gomez, M.I., House, L.R., Rooney, L.W. and Dendy, D.V., Eds., Utilization of Sorghum and Millets, ICRISTAT, Patancheruvu, 67-73.

[2] Gernah, D.I., Ariahu, C.C. and Umeh, E.U. (2012) Physical and Microbiological Evaluation of Food Formulations from Malted and Fermented Maize Fortified with Defatted Sesame Flour. Advance Journal of Food Science and Technology, 4, 148-154.

[3] Igbabul, B.D., Amove, J. and Okoh, A. (2014) Quality Evaluation of Composite Bread Produced from Wheat, Defatted Soy and Banana Flours. International Journal of Nutrition and Food Science, 3, 471-476. https://doi.org/10.11648/j.ijnfs.20140305.26

[4] Jideani, V.A. and Onwubali, F.C. (2009) Optimisation of Wheat-Sprouted Soybean Flour Bread Using Response Surface Methodology. African Journal of Biotechnology, 8, 6364-6373. https://doi.org/10.5897/AJB09.707

[5] Ndife, J. and Abbo, E. (2009) Functional Foods: Prospects and Challenges in Nigeria. Journal of Food Science and Technology, 1, 1-6.

[6] Oburuoga, A.C. and Anyika, J.U. (2012) Nutrient and Antinutrient Composition of Mung Bean (Vigna radiata), Acha (Digitana exilis) and Crayfish (Astacus fluriatilis) Flours. Pakistan Journal of Nutrition, 11, 841-844. https://doi.org/10.3923/pjn.2012.841.844

[7] Rosa, N.N., Barron, C., Gaiani, C., Dufour, C. and Micard, V. (2013) Ultra-Fine Grinding Increases the Antioxidant Capacity of Wheat Bran. Journal of Cereal Sci- 
ence, 57, 84-90. https://doi.org/10.1016/j.jcs.2012.10.002

[8] Ebert, A.W. (2014) Potential of Underutilized Traditional Vegetables and Legume Crops to Contribute to Food and Nutritional Security, Income and More Sustainable Production Systems. Sustainability, 6, 319-335.

https://doi.org/10.3390/su6010319

[9] Bibiana, I., Grace, N. and Julius, A. (2014) Quality Evaluation of Composite Bread Produced from Wheat, Maize and Orange fleshed Sweet Potato Flours. American Journal of Food Science and Technology, 2, 109-115.

https://doi.org/10.12691/ajfst-2-4-1

[10] Grieshop, C.M., Kadzere, C.T., Clapper, G.M., Flickinger, E.A., Bauer, L.L., Frazier, R.L. and Fahey Jr., G.C. (2003) Chemical and Nutritional Characteristics of United States Soybeans and Soybean Meals. Journal of Agriculture and Food Chemistry, 51, 7684-7691. https://doi.org/10.1021/jf034690c

[11] Dilger, R.N., Sands, J.S., Ragland, D. and Adeola, O. (2004) Digestibility of Nitrogen and Amino Acids in Soybean Meal with Added Soyhulls. Journal of Animal Science, 82, 715-724. https://doi.org/10.2527/2004.823715x

[12] Messina, M. (1999) Legumes and Soybeans: Overview of Their Nutritional Profiles and Health Effects. American Journal Clinical Nutrition, 70, 439S-450S. https://doi.org/10.1093/ajcn/70.3.439s

[13] Altunkaya, A., Hedegaard, R.V., Brimer, L., Gokmen, V. and Skibsted, L.H. (2013) Antioxidant Capacity versus Chemical Safety of Wheat Bread Enriched with Pomegranate Peel Powder. Food \& Function, 4, 722-727.

https://doi.org/10.1039/c3fo30296b

[14] Giami, S.Y., Mepha, H.D., Kiinkabari, D.B. and Achinewu, S.C. (2003) Evaluation of the Nutritional Quality of Breads Prepared from Wheat-Fluted Pumpkin (Telfairiaoccidentalis) Seed Flour Blends. Plant Foods for Human Nutrition, 58, 217-226. https://doi.org/10.1023/B:QUAL.0000041167.61992.4d

[15] Bichi, M.H. (2013) A Review of the Applications of Moringa oleifera Seeds Extract in Water Treatment. Civil and Environmental Research, 3, 1-10.

[16] Moyo, B., Masika, P.J., Hugo, A. and Muchenje, V. (2013) Nutritional Characterization of Moringa (Moringa oleifera Lam.) Leaves. African Journal of Biotechnology, 10, 12925-12933. https://doi.org/10.5897/AJB10.1599

[17] Fernandes, D.M., Sousa, R.M., de Oliveira, A., Morais, S.A., Richter, E.M. and Muñoz, R.A. (2015) Moringa oleifera: A Potential Source for Production of Biodiesel and Antioxidant Additives. Fuel, 146, 75-80. https://doi.org/10.1016/j.fuel.2014.12.081

[18] Santos, A.F., Luz, L.A., Pontual, E.V., Napoleão, T.H., Paiva, P.M. and Coelho, L.C. (2015) Moringa oleifera: Resource Management and Multiuse Life Tree. Advances in Research, 4, 388-402. https://doi.org/10.9734/AIR/2015/18177

[19] Olson, M.E., Sankaran, R.P., Fahey, J.W., Grusak, M.A., Odee, D. and Nouman, W. (2016) Leaf Protein and Mineral Concentrations across the "Miracle Tree" Genus Moringa. Journal of food Science, 11, 0159782. https://doi.org/10.1371/journal.pone.0159782

[20] Akubor, P.I., Onoja, S.U. and Umego, C.E. (2013) Quality Evaluation of Fried Noodles Prepared from Wheat, Sweet Potato and Soybean Flour Blends. Journal of $\mathrm{Nu}$ trition Ecology Food Research, 1, 281-287. https://doi.org/10.1166/jnef.2013.1039

[21] Aye, P. (2016) Comparative Nutritive Value of Moringa oleifera, Tithonia diversifolia and Gmelina arborea Leaf Meals. American Journal of Food Nutrition, 6, 23-32. 
[22] AOAC (2015) Official Methods of Analysis. Association of Official Analytical Chemists. 18th Edition, AOAC, Arlington, 806-814.

[23] Egounlety, M. (2001) Production Properties and Utilization of Mould Fermented Foods from Soybean (Glycine max. M.) Cowpea (Vigna unguiculata l. Walp) and Ground Bean (Macrotyloma geocarpa H.). Ph.D. Thesis, University of Ibadan, Ibadan, 21-28.

[24] Sathe, A.K., Deshphande, S.S. and Salunke, D.K. (1982) Functional Properties of Lupine Seed (Lupinus mutabillia) Proteins and Protein Concentrates. Journal of Food Science, 47, 491-497. https://doi.org/10.1111/j.1365-2621.1982.tb10110.x

[25] Onimawo, I.A. and Egbekwun, M.K. (1998) Comprehensive Food Science and Nutrition, Revised Edition. Ambik Publisher, Benin City.

[26] Sosulski, F.W., Humbert, E.S., Bui, E.S. and Jones, J.I. (1976) Functional Properties of Rapeseed Flours Concentrates and Isolates. Journal Food Science, 41, 1349-1351. https://doi.org/10.1111/j.1365-2621.1976.tb01168.x

[27] Coffman, C.W. and Garcia, V.V. (1977) Functional Properties and Amino Acid Content of Protein Isolate from Mung Bean Flour. Journal Food Technology, 12, 473-484. https://doi.org/10.1111/j.1365-2621.1977.tb00132.x

[28] Atuonwu, A.C., Onwuka, G.I. and Ibeawuchi, G.I. (2010) Comparative Study on the Role of Food Gums in the Production of Cocoa-Enriched Candies. Nigerian Food Journal, 28, 96-198. https://doi.org/10.4314/nifoj.v28i1.57432

[29] Ikpeme, C.A., Osuchukwu, N.C. and Oshieel, L (2010) Functional and Sensory Properties of Wheat (Aestium triticium) and Taro Flour (Colocasia esculenta) Composite Bread. African Journal of Food Science, 4, 248-253.

[30] Ukpabi, U.J. and Ndimele, C. (1990). Evaluation of the Quality of Gari Produced in Imo State. Nigerian Food Journal, 1, 105-110.

[31] Onwuka, G.I. (2005) Food Analysis and Instrumentation, Theory and Practice. HG Support Press, Lagos, 64-92.

[32] Lee, G.F. and Stumm, W. (1960) Determination of Ferrous Iron in the Presence of Ferric Iron Using Bathopenanthroline. Journal of American Water Works Association, 52, 1567. https://doi.org/10.1002/j.1551-8833.1960.tb00631.x

[33] Osborne, D.R. and Voogt, P. (1978) The Analysis of Nutrients in Foods. Academic Press, London, 160-239.

[34] Pearson, D. (1976) The Chemical Analysis of Foods. 7th Edition, Churchill Livingstone, London.

[35] Association of Official Analytical Chemist (AOAC) (2010) Official Methods of Analysis. 18th Edition, Association of Official Analytical Chemists, Arlington, 806-814.

[36] Akiko, H.S. and Young, J. (2014) Functional Bakery Products: Current Directions and Future Opportunities. Food Industrial Journal, 4, 136-144.

[37] Iwe, M.O. (2003) The Science and Technology of Soybean. Rejoint Communications Limited, Enugu, 115-138.

[38] Teixeira, E.M.B., Carvalho, M.R.B., Neves, V.A., Silva, M.A. and Arantes-Pereira, L. (2014) Chemical Characteristics and Fractionation of Proteins from Moringa oleifera Lam. Leaves. Food Chemistry, 147, 51-54.

https://doi.org/10.1016/j.foodchem.2013.09.135

[39] Soetan, K.O., Akinrinde, A.S. and Adisa, S.B. (2014) Comparative Studies on the Proximate Composition, Mineral and Antinutritional Factors in the Seeds and Leaves of African Locust Bean (Parkia biglobosa). Annals of Food Science and 
Technology, 15, 70.

[40] Gidamis, A.B., Panga, J.T., Sarwatt, S.V., Chove, B.E. and Shayo, N.B. (2013) Nutrient and Antinutrient Contents in Raw and Cooked Young Leaves and Immature Pods of Moringa oleifera, Lam. Ecology of Food and Nutrition, 42, 399-411. https://doi.org/10.1080/03670240390268857

[41] Sivakumar, D. (2013) Adsorption Study on Municipal Solid Waste Leachate Using Moringa oleifera Seed. International Journal of Environmental Science and Technology, 10, 113-124. https://doi.org/10.1007/s13762-012-0089-8

[42] Iskandar, I., Hadju, V., As'ad, S. and Natsir, R. (2015) Effect of Moringa oleifera Leaf Extracts Supplementation in Preventing Maternal Anaemia and Low-Birthweight. International Journal of Scientific and Research Publications, 5, 1-3.

[43] Abdelghafor, R.F., Mustafa, A.I., Ibrahim, A.M.H. and Krishnan, P.G. (2011) Quality of Bread from Composite Flour of Sorghum and Hard White Winter Wheat. Advance Journal of Food Science Technology, 3, 9-15.

[44] Nour, A.A.M. and Ibrahim, M.A.E.M. (2016) Effect of Supplementation with Moringa Leaves Powder (MLP) and Fermentation on Chemical Composition, Total minerals Contents and Sensory Characteristics of Sorghum Flour. International Journal of Science Resource, 5, 672-677. https://doi.org/10.21275/v5i3.NOV161822

[45] Alaunyte, I., Stojceska, V., Plunkett, A., Ainsworth, P. and Derbyshire, E. (2012) Improving the Quality of Nutrient Rich Teff (Eragrostis tef) Breads by Combination of Enzymes in Straight Dough and Sourdough Bread Making. Journal of Cereal Science, 55, 22-30. https://doi.org/10.1016/j.jcs.2011.09.005

[46] Mohamed Nour, A.A. (2013) Chemical and Nutritional Quality of Millet Flour Supplemented with Moringa or Fenugreek Seeds Flour, Ph.D. Thesis, Omdurman Islamic University, Khartoum.

[47] Steyn, N.P. and Mchiza, Z.J. (2014) Obesity and the Nutrition Transition in Sub-Saharan Africa. Annals of the New York Academy of Sciences, 1311, 88-101. https://doi.org/10.1111/nyas.12433

[48] Freire, W.B., Silva-Jaramillo, K.M., Ramírez-Luzuriaga, M.J., Belmont, P. and Waters, W.F. (2014) The Double Burden of Undernutrition and Excess Body Weight in Ecuador. The American Journal of Clinical Nutrition, 100, 1636S-1643S. https://doi.org/10.3945/ajen.114.083766

[49] Mbwana, H.A., Kinabo, J., Lambert, C. and Biesalski, H.K. (2016) Determinants of Household Dietary Practices in Rural Tanzania: Implications for Nutrition Interventions. Cogent Food and Agriculture, 2, 1224046.

https://doi.org/10.1080/23311932.2016.1224046

[50] Wang, J., Rosell, C.M. and Barber, C.B. (2002) Effect of the Addition of Different Fibres on Wheat Dough Performance and Bread Quality. Food Chemistry, 79, 221-226. https://doi.org/10.1016/S0308-8146(02)00135-8

[51] Soliva, C.R., Kreuzer, M. and Foidl, N. (2005) Feeding Value of Whole and Extracted Moringa oleifera Leaves for Ruminants and Their Effects on Ruminal Fermentation in Vitro. Animal Feed Science and Technology, 118, 47-62.

https://doi.org/10.1016/j.anifeedsci.2004.10.005

[52] Natal, D.I.G., Dantas, M.I.S., Vidigal, M.C.T.R., Ribeiro, S.M.R., Silva, R.R. and Martino, H.S.D. (2013) Physical and Sensorial Properties of Potato Read Fortified with Whole Soybean Flour. Revista Chilena De Nutricion, 40, 62-70. https://doi.org/10.4067/S0717-75182013000100010

[53] Hager, A.S., Ryan, L.A.M., Schwab, C., Gänzle, M.G., O’Doherty, J.V. and Arendt 
E.K. (2011) Influence of the Soluble Fibres Inulin and Oat $\beta$-Glucan on Quality of Dough and Bread. European Food Research and Technology, 232, 405-413. https://doi.org/10.1007/s00217-010-1409-1

[54] Coskuner, Y. and Karababa, E. (2005) Studies on the Quality of Turkish Flat Breads Based on Blends of Triticale and Wheat Flour. International Journal of Food Science and Technology, 40, 469-479. https://doi.org/10.1111/j.1365-2621.2005.00925.x

[55] Olaoye, O.A., Onilude, A.A. and Idowu, O.A. (2006) Quality Characteristics of Bread Produced from Composite Powders of Wheat, Plantain, and Soybeans. African Journal of Biotechnology, 5, 1102-1106.

[56] Adeleke, R.O. and Odedeji, J.O. (2010) Acceptability Studies on Bread Fortified with Tilapia Fish Flour. Pakistan Journal of Nutrition, 9, 531-534. https://doi.org/10.3923/pjn.2010.531.534

[57] Abioye, V.F. and Aka, M.O. (2015) Proximate Composition and Sensory Properties of Moringa Fortified Maize-Ogi. Journal of Nutrition and Food Science, S12, 1-4.

[58] Chinma, C.E., Igbabul, B.D. and Omotayo, O.O. (2012) Quality Characteristics of Cookies Prepared from Unripe Plantain and Defatted Sesame Flour Blends. American Journal of Food Technology, 7, 398-408. https://doi.org/10.3923/ajft.2012.398.408

[59] Haneen, H.S.M. (2015) Effect of Dried Moringa oleifera Leaves on the Nutritional and Organoleptic Characteristics of Cookies. Alexandria Science Exchange Journal, 36, 297-305. https://doi.org/10.21608/asejaiqjsae.2015.2934

[60] Umelo, M.C., Nsofor, A.E., Akajiaku, L.O., Odimegwu, E.N., Uzoukwu, A.E., Agunwah, I.M., Eluchie, C.N., Alagbaoso, S.O. and Njoku, N.E. (2014) Effect of Different Dough Improvers on the Proximate Composition, Minerals, Vitamins, and Sensory Properties of Wheat Bread. International Journal of Science Research Innovative Technology, 1, 112-126.

[61] Sengev, A.I., Abu, J.O. and Gernah, D.I. (2013) Effect of Moringa oleifera Leaf Powder Supplementation on Some Quality Characteristics of Wheat Bread. Food and Nutrition Sciences, 4, 270-275. https://doi.org/10.4236/fns.2013.43036

[62] Shalini, K.G. and Laxmi, A. (2007) Influence of Additives on Rheological Characteristics of Whole-Wheat Dough and Quality of Chapatti (Indian Unleavened Flat Bread) Part I-Hydrocolloids. Food Hydrocolloids, 21, 110-117. https://doi.org/10.1016/j.foodhyd.2006.03.002

[63] Sullivan, P., O’Flaherty, J., Brunton, N., Arendt, E. and Gallagher, E. (2010) Fundamental Rheological and Texture Properties of Doughs and Breads Produced from Milled Pearled Barley Flour. European Food Research and Technology, 231, 441-453. https://doi.org/10.1007/s00217-010-1297-4 